7. Reprod. Fert. (1972) 28, 41-54

\title{
THE PERMEABILITY OF BULL SPERMATOZOA TO WATER, POLYHYDRIC ALCOHOLS AND UNIVALENT ANIONS AND THE EFFECTS OF THE ANIONS UPON THE KINETIC ACTIVITY OF SPERMATOZOA AND SPERM MODELS
}

\author{
L.-O. DREVIUS \\ Institute of Zoophysiology, University of Uppsala, Sweden
}

(Received 4th December 1970, accepted 1st June 1971)

\begin{abstract}
Summary. The times for epididymal bull spermatozoa to undergo swelling-induced lysis in water and in isosmotic solutions of penetrating polyhydric alcohols were determined by microscopical observations. The permeability of the spermatozoa to inorganic anions was studied by an indirect method, involving spermatocrit determinations on cells suspended in different ammonium-Ringer solutions. The effects of the anions and of caffeine on the kinetic activity of spermatozoa and sperm models were studied by the 'sperm-rise' test and microscopical observations. The following results were obtained. (1) The rates of permeation of the sperm membrane of the different polyols investigated followed the series erythritol $>$ adonitol $>$ D-arabitol $>$ sorbitol $>$ L-arabitol, mannitol, dulcitol. (2) Bull spermatozoa seem to have a permeability to univalent inorganic anions which is greater than that to cations. The penetration rates of the different anions seem to obey the series $\mathrm{SCN}^{-}>\mathrm{NO}_{3}{ }^{-}>\mathrm{I}^{-}>$ $\mathrm{Br}^{-}, \mathrm{Cl}^{-}$. (3) Fluoride appears to penetrate preferably in the form of $\mathrm{HF}$, a conclusion also drawn by previous authors on the basis of other types of experiments. (4) $\mathrm{Br}^{-}$and caffeine both potentiated the sperm kinetic activity and $\mathrm{Br}^{-}$that of the sperm models.
\end{abstract}

\section{INTRODUCTION}

In recent investigations, the osmotic-equilibrium states of bull spermatozoa have been given a preliminary analysis (Drevius, 1972a) and the osmotic behaviour of the spermatozoa in hypotonic media has been studied (Drevius, 1972b). It was found that the bull spermatozoa from the cauda epididymidis behave as osmometers with values of Ponder's factor $R$ (Ponder, 1940) in the range 0.81 to 0.91 . In the present study, the permeability of the spermatozoa to water and to polyols is the subject of an introductory analysis. In addition, reports will be presented on the permeability of bull spermatozoa to univalent inorganic ions and on the effects of anions upon the motility of spermatozoa and sperm models. 


\section{MATERIAL AND METHODS}

Bull spermatozoa were obtained from the cauda epididymidis of gonads from slaughtered bulls and collected in $\mathrm{NaCl}$ Ringer solution (see below) as in previous studies (Drevius, 1971a, 1972a, b).

The concentration of spermatozoa in different test suspensions was adjusted to $0.5 \%$ with the aid of the preliminary test described by Drevius (1971a). A sample $(2.0 \mathrm{ml})$ of a given test suspension made up in isotonic, $0.191 \mathrm{M}-\mathrm{NaCl}$ Ringer (see below) will, provided that the spermatozoa are immotile, give a spermatocrit of $0.010 \mathrm{ml}$ when centrifuged for $15 \mathrm{~min}$ at $2000 \mathrm{~g}$ in tubes of the type described in Drevius (1971a).

\section{Suspending media for different experiments}

(A) The influence upon sperm motility of different anions was investigated by the 'sperm-rise' test (Drevius, 1971a, and below) on cells suspended in media consisting of the Ringer solution described by Mann (1964), in which the 100 $\mathrm{ml}$ of $0.9 \%(0.154 \mathrm{M}-) \mathrm{NaCl}$ component was replaced with $0.191 \mathrm{M}-\mathrm{NaCl}$, or with 0.191 м solutions of $\mathrm{NaNO}_{3}, \mathrm{NaBr}, \mathrm{NaI}$ or NaSCN. The osmolalities of these Ringer solutions are approximately 0.353 osmol, i.e. they are isosmotic with the fluids from the cauda epididymidis (see Drevius, 1972a). The solutions also contained $0.1 \%$ of glucose.

(B) The permeability to different polyhydric alcohols was studied in cells suspended in 0.353 osmol solutions of $m$-erythritol, D-adonitol, D-arabitol, L-arabitol, D-mannitol, D-sorbitol and D-dulcitol. These solutions also contained the $\mathrm{NaHCO}_{3}$ and $\mathrm{KH}_{2} \mathrm{PO}_{4}$ components which constitute the buffering system in Mann's Ringer solution.

(C) Volume changes in spermatozoa in $0.154 \mathrm{M}$-ammonium-Ringer solutions were observed by microscopy and recorded by spermatocrit determinations (see below). The solutions consisted of Mann's Ringer solution, in which the $100-\mathrm{ml} \mathrm{NaCl}$ component was replaced with $0.154 \mathrm{M}$ solutions of $\mathrm{NH}_{4} \mathrm{Cl}$, $\mathrm{NH}_{4} \mathrm{NO}_{3}, \mathrm{NH}_{4} \mathrm{Br}, \mathrm{NH}_{4} \mathrm{I}, \mathrm{NH}_{4} \mathrm{SCN}$ or $\mathrm{NH}_{4} \mathrm{~F}$, respectively. These solutions are isosmotic with seminal plasma.

\section{Sperm models}

Loss of cell-membrane integrity was induced by normal rabbit serum with well-established spermolytic activity (cf. Drevius, 1968). The kinetic activity of spermatozoa and models was investigated in solutions consisting of one part of serum + four parts of $0.191 \mathrm{~m}-\mathrm{NaCl}$ Ringer, $\mathrm{NaNO}_{3}$ Ringer, $\mathrm{NaBr}$ Ringer, NaI Ringer, NaSGN Ringer or NaF Ringer, respectively, and in solutions as above but containing 2 mm-ATP. In addition, the solutions usually contained $6 \%$ of Ficoll.

Pretreatment of spermatozoa used in $(B)$ and $(C)$ above

The procedure is described here for spermatozoa subsequently investigated in ammonium-Ringer solutions by spermatocrit determinations.

For each experiment, a volume of stock suspension was taken which, if diluted with $80 \mathrm{ml}$ of an isotonic medium, would yield a $0.5 \%$ suspension. Such a volume was diluted in $80 \mathrm{ml}$ of a mixture of 1 vol. $0 \cdot 191 \mathrm{M}-\mathrm{NaCl}$ and 5 vol. 
water. The spermatozoa rapidly swelled to osmotic equilibrium and the granular contents of the cytoplasmic droplet were emptied into the vesicle which consisted of the distorted flagellar part of the cell membrane. Solid $\mathrm{NaCl}$ was then added to a final concentration of $0.154 \mathrm{M}$ (in experiments in which the spermatozoa were to be subsequently studied in the polyol solutions: $0.191 \mathrm{M}$ ), while the suspension was gently shaken. The coiled swollen spermatozoa underwent dehydration and uncoiling and the cytoplasmic-droplet material was transferred to the distal part of the tail, where it became localized inside a slight bulge of the membrane (Text-fig. 1 B; cf. Drevius \& Eriksson, 1966).
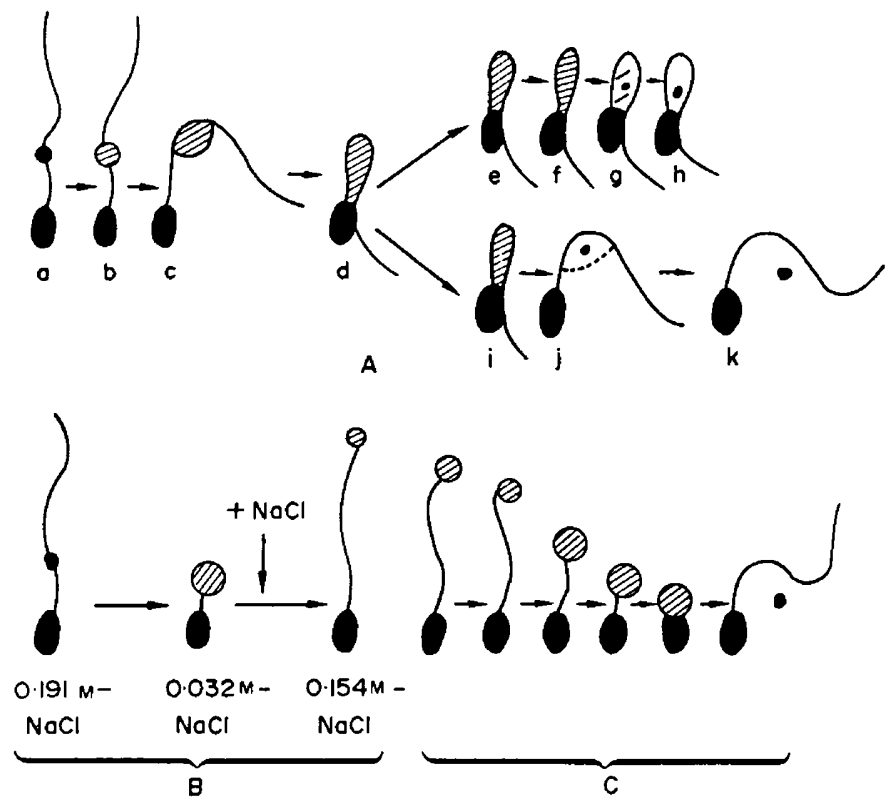

TexT-FIG. 1. (A) Configuration changes in bull epididymal spermatozoa associated with their swelling and subsequent lysis in ammonium Ringer solutions and in media of slowly penetrating polyols(L-arabitol, mannitol, dulcitol). (B) Experimentally induced transfer of cytoplasmic droplet material from the mid-piece region to the tail tip. (C) 'Ideal' swelling of spermatozoa, pretreated as in (B), in solutions mentioned under A. $A$ to $\mathrm{C}$ : Spermatozoa indicated by hatched regions are swollen. Dots indicate cytoplasmic droplet material (cf. micrographs in Drevius \& Eriksson, 1966; Drevius, 1968).

Appropriate numbers of $10 \cdot 0-\mathrm{ml}$ aliquots were then transferred to ordinary centrifuge tubes. The spermatozoa were spun down (1500 $\mathrm{g}$ for $10 \mathrm{~min}$ ) and the supernatants were rapidly decanted. They were replaced with $10 \cdot 0-\mathrm{ml}$ vol. of different ammonium-Ringer solutions, and the cells were thoroughly resuspended. Aliquots of $2.0 \mathrm{ml}$ of these suspensions were then centrifuged at intervals in spermatocrit tubes for $15 \mathrm{~min}$ at $2000 \mathrm{~g}$ and the changes in spermatocrits were registered.

\section{The influence of different anions on the sperm kinetic activity}

This was studied by the 'sperm-rise' test (Drevius, 1971a). The extension of the cell columns caused by the motility of the spermatozoa was registered in spermatocrit tubes after centrifugation of $2 \cdot 0-\mathrm{ml}$ aliquots of the different $0.5 \%$ 
test suspensions for $15 \mathrm{~min}$ at $2000 \mathrm{~g}$ at 23 to $24^{\circ} \mathrm{C}$. Readings were made immediately after the centrifuge stopped (deceleration time $2 \mathrm{~min}$ ) and then after a further 5,10 and 15 min. Intervals between the preparation of suspensions and the running of spermatocrits were $0,1 \frac{1}{2}$ and $3 \mathrm{hr}$. 'Sperm rises' are expressed as percentages of the true spermatocrit $(0.010 \mathrm{ml})$, i.e. the value obtained in a fluoride-containing control suspension with identical cell concentration and in which the spermatozoa were non-motile (for further information, see Drevius, 1971a).

\section{Determination of the times for spermolysis in different polyol solutions and in distilled water}

Spermatozoa which had undergone the treatment indicated in Text-fig. 1 B were, after centrifugation and removal of the supernatant, suspended in the different polyol solutions both with and without $6 \%$ Ficoll. Small samples of the suspensions were repeatedly observed in thin slide-coverslip preparations under a phase-contrast microscope. The times when an estimated 70 to $80 \%$ of the cells had undergone spermolysis were recorded. In Ficoll-containing solutions, the diluted cytosol of swelling spermatozoa contrasts brightly with the medium as long as the sperm-membrane integrity persists (the immersionrefractometry method of Barer, 1956; cf. Drevius \& Eriksson, 1966; Drevius 1968). In distilled water, the actual time was estimated from numerous experiments performed as follows. A small but dense drop of spermatozoa from a suspension previously centrifuged for $10 \mathrm{~min}$ at $3000 \mathrm{~g}$ was mounted as a slide-coverslip preparation and its margin was focused under the microscope. Water was allowed to diffuse into the preparation from a drop at the edge of the coverslip. At the meeting with the water-front, the spermatozoa were seen to coil rapidly and then abruptly to straighten out, indicating sperm swelling and subsequent membrane rupture (cf. Text-fig. $1 \mathrm{C}$ ).

The organic compounds used in the present study were Ficoll, mol. wt $\sim 400,000$, chloride (as NaCl) $<1 \%$. Lot No. To 5987 (Pharmacia AB), m-erythritol, Darabitol and L-arabitol (British Drug Houses Ltd), D-adonitol (Nutritional Biochemical Corporation), D-sorbitol and D-dulcitol (Merck), D-mannitol (Difco) and ATP (Sigma, disodium salt).

\section{RESULTS}

Volume changes and lysis of spermatozoa in polyol solutions and ammonium-Ringer solutions

Untreated spermatozoa in ammonium-Ringer solutions were observed under the microscope to undergo a gradual swelling towards spermolysis of the type illustrated in Text-fig. $1 \mathrm{~A}$, as did spermatozoa in polyol solutions of L-arabitol, mannitol and dulcitol where the induced swelling was slow (cf. Table 1). In polyol solutions in which sperm swelling was more rapid (erythritol, adonitol and D-arabitol), it was of the 'ideal' type shown in Text-fig. 1 C, i.e. the swelling gave rise to a final cell volume of the same magnitude as that of epididymal bull spermatozoa in hypotonic saline media of critical tonicity (cf. Drevius, $1972 \mathrm{~b})$. In the sorbitol solution, certain cells swelled 'ideally', others not. 
The times for spermolysis in the different polyol solutions (Table 1) were determined on 'ideally' swelling spermatozoa (Text-fig. $1 \mathrm{C}$ ) which had been subjected to the pretreatment indicated in Text-fig. I B before suspension in polyol. The exact times of spermolysis were difficult to determine in solutions of L-arabitol, mannitol and dulcitol since at the time when the critical sperm

TABLE 1

TIMES FOR THE INDUCTION OF ' $75 \%$ SPERMOLYSIS' IN BULL EPIDIDYMAL SPERMATOZOA IN WATER AND DIFFERENT ISOSMOTIC POLYOL SOLUTIONS

\begin{tabular}{c|c}
\hline Substance & Spermolysis time (sec) \\
\hline Water & 2 \\
m-Erythritol & $87(81$ to 91$)$ \\
Adonitol & $134(130$ to 142$)$ \\
D-Arabitol & $590(577$ to 612$)$ \\
L-Arabitol & $12600(3200(3120$ to 3260$)$ \\
Sorbitol & 3200 \\
Mannitol & $\sim 12600$ \\
Dulcitol & $\sim 12600$ \\
\hline
\end{tabular}

The experiments (five) were carried out at $25^{\circ} \mathrm{C}$. For further information, see text.

volume was attained, membrane integrity was not abolished abruptly (as in Text-fig. $1 \mathrm{C}$ ). This became evident from the fact that in suspensions in which Ficoll was present, the bright contrast of the greatly swollen spermatozoa disappeared gradually during a period of 1 to $10 \mathrm{~min}$. In these spermatozoa, the motor apparatus remained coiled inside the leaky membrane envelope. These processes will be discussed elsewhere.

Spermatocrit determinations on spermatozoa in ammonium-Ringer solutions

The swelling rates of spermatozoa in different ammonium-Ringer solutions of pH 7.0 and 7.8 are demonstrated in Text-figs. 2 and 3. The adjustment of the $\mathrm{pH}$ was made with $0.2 \mathrm{M}-\mathrm{NaOH}$. The continuous lines indicate periods within which spermatozoa were continuously swelling, whereas broken lines indicate times where increasing numbers of spermatozoa are undergoing spermolysis. In the corresponding sodium-Ringer solutions, the hydration states of the spermatozoa were unaffected for periods of up to $3 \mathrm{hr}$, with the exception of the NaSGN-Ringer solution, in which there was a slight increase in sperm volume of the same magnitude as that in the $\mathrm{NH}_{4} \mathrm{Br}$-Ringer solution. Spermatocrit determinations on spermatozoa in 0.191 and $0.154 \mathrm{M}-\mathrm{NaCl}$ Ringer solutions showed that the values in the latter solution were approximately $10 \%$ higher than in the former (Drevius, 1972a, b). For this reason, zero-time spermatocrit values in Text-figs. 2 and 3 are given as 0.011 . The swelling rates of the individual spermatozoa in a given suspension vary considerably, which implies that all the spermatozoa do not reach their critical volume and undergo membrane rupture at one and the same time. This fact, as well as others, discussed in Drevius (1972b) explain that the spermatocrits recorded in Text-figs. 2 and 3 are con- 


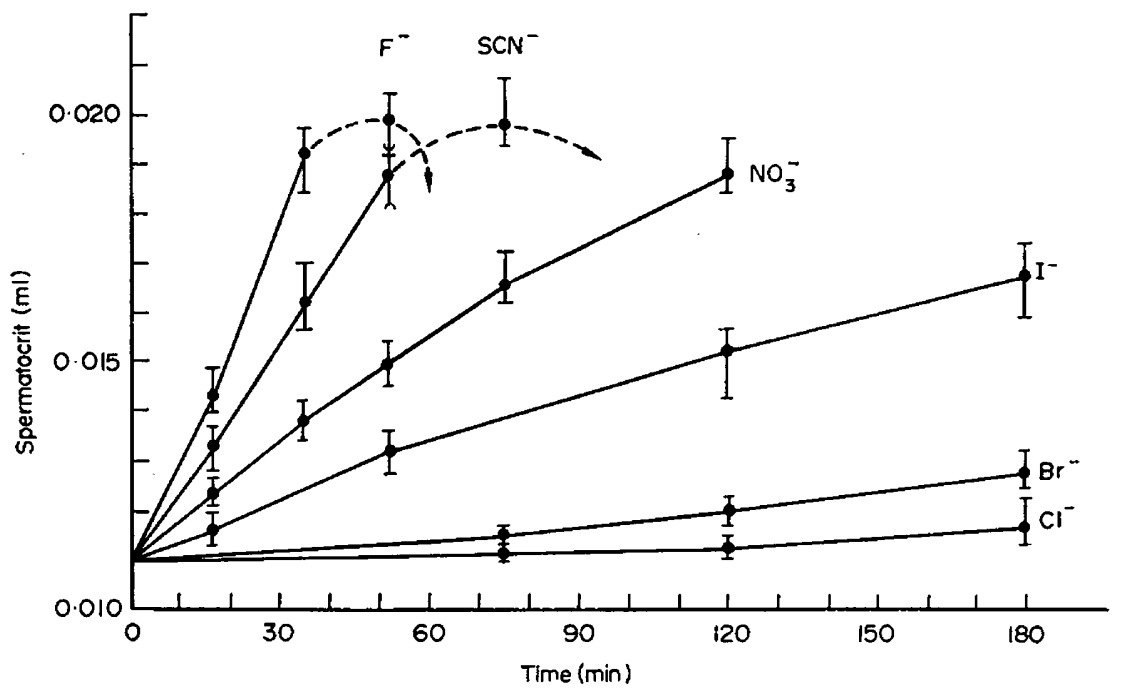

Text-Fig. 2. Increase of spermatocrits with time of suspensions of spermatozoa in $\mathrm{NH}_{4} \mathrm{~F}$ Ringer, $\mathrm{NH}_{4} \mathrm{SCN}$ Ringer, $\mathrm{NH}_{4} \mathrm{NO}_{3}$ Ringer, $\mathrm{NH}_{4} \mathrm{I}$ Ringer, $\mathrm{NH}_{4} \mathrm{Br}$ Ringer and $\mathrm{NH}_{4} \mathrm{Cl}$ Ringer solutions at $\mathrm{pH}=7.0$ (means and ranges of four experiments).

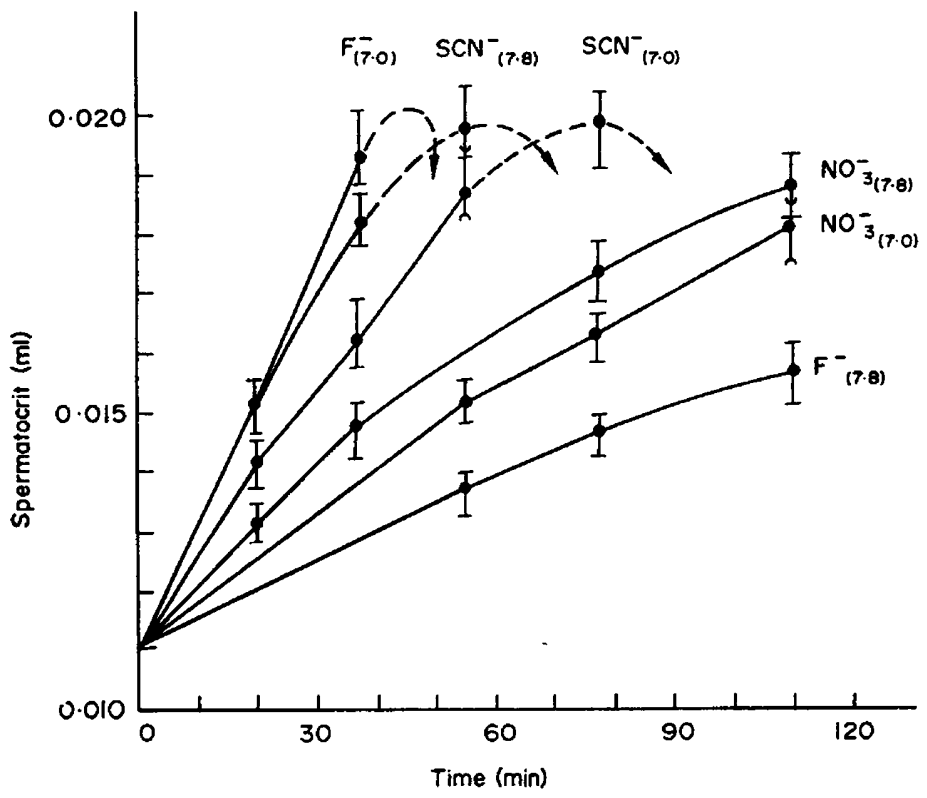

TexT-FIG. 3. Increase of spermatocrits with time in suspensions of spermatozoa in $\mathrm{NH}_{4} \mathrm{~F}$ Ringer, $\mathrm{NH}_{4} \mathrm{SCN}$ Ringer and $\mathrm{NH}_{4} \mathrm{NO}_{3}$ Ringer solutions at $\mathrm{pH} 7.0$ and 7.8 (means and ranges of three experiments). 


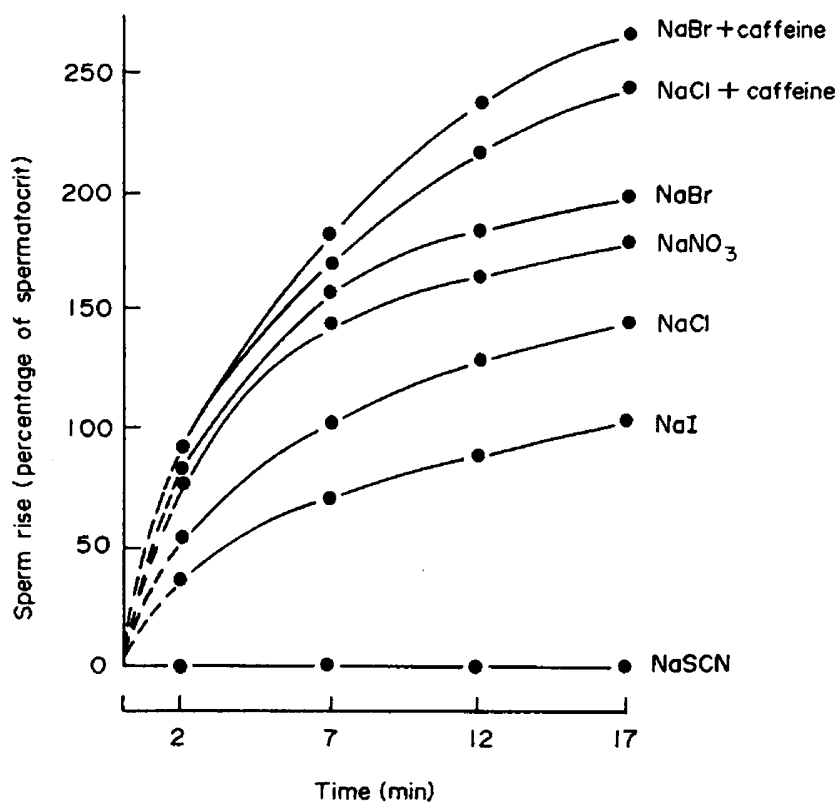

TExT-Fig. 4. Influence on the 'sperm rise' of different anions and of $2 \times 10^{-3} \mathrm{M}$-caffeine. Results are from the $1 \frac{1}{2}$-hr interval of a single experiment (see Table 2).

\section{TABLE 2}

MEANS AND RANGES OF 'SPERM-RISE' VALUES, EXPRESSED AS PERGENTAGES OF INITIAL SPERMATOCRITS $(0.010 \mathrm{ML})$, FOR SUSPENSIONS OF BULL EPIDIDYMAL SPERMATOZOA IN DIFFERENT TEST MEDIA FOUND AT THE 17-MIN READING INTERVAL AFTER GENTRIFUGATIONS PERFORMED AFTER 0, 1.5 AND 3 HR OF STORAGE OF THE SUSPENSIONS $(n=4)$

\begin{tabular}{|c|c|c|c|}
\hline Suspending media & $0 \mathrm{hr}$ & $1 \frac{1}{2} h r$ & $3 h r$ \\
\hline $\begin{array}{l}\text { (1) } \mathrm{NaCl} \text { Ringer } \\
\text { (2) NaNO } 3 \text { Ringer } \\
\text { (3) } \mathrm{NaI} \text { Ringer } \\
\text { (4) } \mathrm{NaBr} \text { Ringer } \\
\text { (5) } \mathrm{NaCl} \text { Ringer }+2 \times 10^{-3} \mathrm{M}- \\
\text { caffeine } \\
\text { (6) } \mathrm{NaBr} \text { Ringer }+2 \times 10^{-3} \mathrm{M} \text { - } \\
\text { caffeine }\end{array}$ & $\begin{array}{l}86(65 \text { to } 120) \\
90(55 \text { to } 135) \\
75(50 \text { to } 120) \\
129(75 \text { to } 160) \\
192(170 \text { to } 215) \\
214(175 \text { to } 250)\end{array}$ & $\begin{array}{l}118(100 \text { to } 135) \\
127(100 \text { to } 180) \\
97(65 \text { to } 150) \\
195(150 \text { to } 265) \\
218(175 \text { to } 240) \\
248(195 \text { to } 295)\end{array}$ & $\begin{array}{l}106(80 \text { to } 140) \\
98(60 \text { to } 175) \\
80(55 \text { to } 150) \\
206(150 \text { to } 270) \\
204(185 \text { to } 230) \\
252(230 \text { to } 275)\end{array}$ \\
\hline $\begin{array}{l}\text { No. of experiments in which } \\
(2)>(1) \\
(3)>(1) \\
(3)>(2) \\
(4)>(2) \\
(5)>(4) \\
(6)>(5)\end{array}$ & $\begin{array}{l}3 \\
1 \\
0 \\
4 \\
4 \\
4\end{array}$ & $\begin{array}{l}2 \\
1 \\
0 \\
4 \\
3 \\
4\end{array}$ & $\begin{array}{l}2 \\
1 \\
0 \\
4 \\
3 \\
4\end{array}$ \\
\hline
\end{tabular}


siderably less than those expected on the basis of the fact that the critical sperm volume is 3.78 to 3.94 times greater than the isotonic volume.

Sperm motility was immediately blocked in solutions which contained $\mathrm{F}^{-}$ and $\mathrm{SCN}^{-}$. In the other solutions, motility was only moderate after the pretreatment of the spermatozoa (cf. Text-fig. 1 B). It may be assumed, therefore, that the spermatocrit values were insignificantly affected by the motility of the cells, especially since this decreases continuously as cellular swelling progresses.

\section{Influence of different anions and caffeine on the kinetic activity of living spermatozoa}

In the single experiment illustrated in Text-fig. 4 , the order of effectiveness of anions in inducing 'sperm rise' is the same as the order of their beneficial effects upon the viability of guinea-pig spermatozoa found by Gellhorn (1922). This order was not always encountered, however, despite the fact that pooled sperm material from several gonads was always used. According to the results summarized in Table 2, the general order of effectiveness was $\mathrm{Br}^{-}>\mathrm{NO}_{3}{ }^{-} \gtrless \mathrm{Cl}^{-} \geqq$ $\mathrm{I}^{-} \gg \mathrm{SCN}^{-}$. The effects of $\mathrm{Br}^{-}$and of caffeine are of a long-term nature. The 'sperm rises' were commonly less at $0 \mathrm{hr}$ than at $1 \frac{1}{2} \mathrm{hr}$. This may be a consequence of the transient decrease in respiration which is induced in spermatozoa on exposure to a glycolysable substrate (Lardy \& Phillips, 1941).

\section{Influence of different anions on the kinetic activity of ATP-reactivated sperm models}

In serum Ringer solutions containing $\mathrm{SCN}^{-}$or $\mathrm{F}^{-}$, the motility of fresh spermatozoa is blocked within $30 \mathrm{sec}$. In the other serum Ringer solutions, motility ceases within $8 \mathrm{~min}$, the cells swell slightly, and then subsequently undergo lysis (Drevius, 1968). In the presence of ATP, flagellation of sperm models continued for $2 \frac{1}{2}$ to $4 \frac{1}{2} \mathrm{hr}$ in all serum Ringer solutions, except those containing $\mathrm{SCN}^{-}$or $\mathrm{F}^{-}$. In these, flagellation was suppressed.

The kinetic activity of sperm models was strikingly potentiated by $\mathrm{Br}^{-}:$in one experiment, flagellating cells were found even after $4 \frac{1}{2} \mathrm{hr}$. In this medium, more than $40 \%$ of the models exhibited the same forward progression with rotation as the living spermatozoa. Stop-watch measurements established that velocities up to $50 \mu \mathrm{m} \mathrm{sec}-1$ were not uncommon, even after $1 \mathrm{hr}$. Motility with rotation was also encountered among models in the other serum solutions. However, when occurring, it was of low speed and short duration and was commonly associated with the two-dimensional, non-progressive flagellation described by Bishop \& Hoffman-Berling (1959).

\section{DISCUSSION}

\section{Permeability of bull spermatozoa to water}

Proton-resonance studies performed on red cells and bull spermatozoa suspended in $\mathrm{D}_{2} \mathrm{O}$-containing saline failed to establish an exchange of water across the sperm-cell membrane (Odeblad, 1957). This result seems to support the views of Pursley \& Herman (1950), Rothschild (1959) and Quinn \& White (1969) that mammalian spermatozoa do not swell in hypotonic media (cf. Rothschild, 1962; Mann, 1964), but is in conflict with the results of Kölliker 
(1856), Drevius \& Eriksson (1966), Drevius (1968, 1972 a, b), Bredderman \& Foote (1969) and Foote \& Bredderman (1969). In fact, the osmotic permeability coefficient of bull spermatozoa for water, $234 \times 10^{-4} \mathrm{~cm} \mathrm{sec}^{-1}$, is greater than that of other cells investigated (Drevius, 1971b).

The time of spermolysis in water was approximately $2 \sec$ (Table 1). When the membrane ruptures, the tight coil of the compressed motor apparatus is abruptly widened and the apparatus takes on a configuration which may vary from slightly curved to sinuous (cf. Drevius \& Eriksson, 1966). Except for the fact that the cytoplasmic-droplet material has left most of the lysed spermatozoa and is free in the medium, the cells appear quite normal when viewed under the light microscope.

When the experiments of the present study were performed, no apparatus was available by which an exact instrumental recording of the cellular volume expansion and subsequent lysis induced by water could be made. The time of spermolysis, $2 \mathrm{sec}$, obtained by the simple method used (p. 44) is, however, regarded as a safe upper limit despite the fact that the microscopical observations were disturbed by water currents in the slide-coverslip preparations. It should be added that the activity of the added water will be decreased by 'salts' from the Ringer-solution component of the sperm droplet. Thus, the medium surrounding the swelling and lysing spermatozoa in the margin of the droplet (p. 44) will not be pure water but a very dilute electrolyte solution.

\section{Behaviour of spermatozoa in isosmotic solutions of penetrating polyols}

The sperm cell membrane has its greatest curvature in the cytoplasmic droplet region, which is either located at the distal part of the mid-piece (Text-fig. $1 \mathrm{~A}$ ) or at the tail tip (Text-fig. $1 \mathrm{C}$ ). In both cases, a cellular volume expansion will manifest itself initially in this region with a minimum of change in membrane configuration. A slow cellular swelling according to Text-fig. 1C, during which the motor apparatus is regularly coiled in the distal proximal direction will theoretically take place with less increase in membrane strain than in spermatozoa swelling according to Text-fig. $1 \mathrm{~A}$. This is because proximal membrane parts will be continuously incorporated into the wall of the expanding flagellum vesicle which will maintain a surface-volume ratio approaching that of a sphere (cf. Drevius, 1972b). In slowly (not 'ideally') swelling spermatozoa ('Text-fig. $1 \mathrm{~A}$ ), the cell membrane does not apparently have the capacity to force the motor apparatus to coil when this has attained a 'hair-pin' like configuration. A further volume expansion can, therefore, not occur without an associated increase in membrane area. Since the capacity of the cell membrane to stretch is presumably limited (cf. Drevius, 1972b), the integrity of the membrane will be abolished, bringing about the disappearance of the swollen state of the spermatozoa. Depending on the magnitude of the induced injuries, this may occur gradually or abruptly (Text-figs. $1 \mathrm{~A}$, e to $\mathrm{h}$ and $\mathrm{i}$ to $\mathrm{k}$, respectively). The above discussion does not, however, explain why untreated spermatozoa in media of rapidly penetrating substances (erythritol, adonitol, D-arabitol) (cf. Table 1) underwent swelling of the 'ideal' type (p. 44). The type of swelling involved would appear to be dependent on the factor of cellular water uptake per unit time. 


\section{Permeability of bull spermatozoa to polyols}

The time required for cells to undergo swelling-induced lysis in an isosmotic solution of a penetrating substance is an effective index of the penetration of the substance (Davson \& Danielli, 1952). According to the spermolysis times (Table 1), the rates of penetration of erythritol, adonitol, D-arabitol, L-arabitol, sorbitol mannitol and dulcitol through the bull-sperm membrane are in the ratio $145: 94: 21: 1: 4: 1: 1$.

The actual polyols are all strongly hydrophilic (Bärlund, 1929; the Merck Index, 1960; Handbook of chemistry and physics, Weast \& Selby 1966). According to Danielli's analysis of the penetration of homologous hydrophilic substances through a lipid membrane (Davson \& Danielli, 1952), penetration rates should be erythritol $>$ pentitols $>$ hexitols. However, the 5-carbon compound, Larabitol, penetrated about four times slower than the 6-carbon compound, sorbitol (cf. above). Sorbitol is a natural constituent of bull seminal plasma (King \& Mann, 1959) and is metabolized by the spermatozoa (Mann \& White, 1956; White, 1957; O'Shea \& Wales, 1965) through the participation of a sorbitol dehydrogenase (King \& Mann, 1958). The relatively great permeability of bull spermatozoa to sorbitol may indicate the presence in the cell membrane of a system for 'facilitated transfer' of this substance. A paper presenting permeability coefficients of bull spermatozoa for different polyhydric alcohols will appear elsewhere (Drevius, 1971b).

The haemolysis times of mouse and hedgehog erythrocytes in polyol solutions (Ulrich, 1934; Jacobs, Glassmann \& Parpart, 1938) indicate that these cells have permeabilities for erythritol and penti- and hexitols of nearly the same order as those of the bull epididymal spermatozoa. On the other hand, cattle and human erythrocytes are less permeable to erythritol (the times for ' $75 \%$ haemolysis' in isosmotic erythritol solution being about $8 \mathrm{hr}$ and $2 \mathrm{hr}$, respectively) and are only 'slightly permeable' to adonitol and mannitol (Davson \& Danielli, 1952). The question of whether mammalian spermatozoa exhibit species variations in the rapidity with which various non-electrolytes penetrate the cells remains to be studied.

\section{Swelling and permeability of bull spermatozoa}

A. Swelling of cells in ammonium salt solutions. Erythrocytes have been regarded as unique among cells in that they have a much greater permeability to univalent inorganic anions than to cations (Jacobs, 1940; Davson, 1960). This is considered to be the reason why red cells undergo swelling and subsequent lysis in isosmotic ammonium salt solutions of these anions, whereas other cells investigated seem to be no more permeable to the ions of the ammonium salts than they are to the corresponding salts of $\mathrm{Na}^{+}$and $\mathrm{K}^{+}$(Jacobs \& Parpart, 1938; Jacobs, 1940). The $\mathrm{NH}_{4}{ }^{+}$ion is weakly acid $\left(\mathrm{pK}_{\mathrm{a}}=9 \cdot 25\right)$. Owing to the reaction $\mathrm{NH}_{4}{ }^{+}+\mathrm{H}_{2} \mathrm{O} \rightleftarrows \mathrm{NH}_{3}+\mathrm{H}_{3} \mathrm{O}^{+}$, the ammonia in ammonium salt solutions of physiological $\mathrm{pH}$ will enter the cells and combine with intracellular water to give $\mathrm{NH}_{4}{ }^{+}$and $\mathrm{OH}^{-}$. The increased intracellular concentration of $\mathrm{OH}^{-}$brings about a Gibbs-Donnan redistribution of the anions, in order to maintain the equilibrium: $\left[\mathrm{OH}^{-}\right]_{c} \times\left[\mathrm{A}^{-}\right]_{m}=\left[\mathrm{OH}^{-}\right]_{m} \times\left[\mathrm{A}^{-}\right]_{c}$; where $\mathrm{A}^{-}$is 
the predominant anion of the actual ammonium salt medium and $c$ and $m$ stand for cells and medium, respectively. Owing to this 'molecular-ionic' penetration process (Jacobs, 1940), the erythrocytes continuously gain $\mathrm{NH}_{4}{ }^{+}$ and $\mathrm{A}^{-}$, and undergo an osmotic swelling which terminates in haemolysis. The swelling of bull epididymal spermatozoa in ammonium salt solutions indicates that they also have a preferential anion permeability.

B. Permeability of bull spermatozoa to fuoride. Lindahl \& Wedin (1963) studied the effect of $\mathrm{F}^{-}$at different $\mathrm{pH}$ values upon the motility of bull spermatozoa and concluded that fluoride enters the spermatozoa preferentially as HF. This acid has a $\mathrm{pK}_{\mathrm{a}}$ value of 3.17 (Hägg, 1964). Thus, in a solution of $\mathrm{NH}_{4} \mathrm{~F}$ at physiological $\mathrm{pH}$ there will be a significant concentration of undissociated $\mathrm{HF}$. Weak electrolytes pass cell membranes most rapidly in the undissociated form (Davson, 1960). The rapid swelling of the spermatozoa in the $\mathrm{NH}_{4} \mathrm{~F}$ Ringer solution at $\mathrm{pH} 7.0 \mathrm{may}$, therefore, be due to a penetration into the cells of $\mathrm{NH}_{3}$ and HF (i.e. a 'molecular-molecular' penetration, Jacobs, 1940) occurring simultaneously with, and more rapidly than a 'molecular-ionic' penetration. This idea is supported by the fact that a shift in the $\mathrm{pH}$ of the medium from 7.0 to $7 \cdot 8$, which will increase the amount of available $\mathrm{NH}_{3}$, but decrease the amount of undissociated $\mathrm{HF}$, decreased the rate of swelling of the spermatozoa in the $\mathrm{NH}_{4} \mathrm{~F}$ Ringer solutions (cf. Text-figs. 2 and 3).

C. Permeability of bull spermatozoa to anions of the strong acids. The rates of sperm swelling in the ammonium salt solutions of the strong acids at $\mathrm{pH} 7.0$ were determined by the anions in the order $\mathrm{SCN}^{-}>\mathrm{NO}_{3}{ }^{-}>\mathrm{I}^{-}>\mathrm{Br}^{-}, \mathrm{Cl}^{-}$(Textfig. 2). The $\mathrm{pK}_{\mathrm{a}}$ values of $\mathrm{HI}, \mathrm{HBr}, \mathrm{HCl}$ and $\mathrm{HNO}_{3}$ are $\sim-9, \sim-8, \sim-7$ and -1.35 , respectively (Hägg, 1964), whereas the $\mathrm{K}_{\mathrm{a}}$ value of HSCN, 0.85 (Silleń \& Martell, 1964) implies a $\mathrm{pK}_{\mathrm{a}}$ value of 0.07 . A shift in the $\mathrm{pH}$ from 7.0 to $7 \cdot 8$ in the $\mathrm{NH}_{4} \mathrm{SGN}$ and $\mathrm{NH}_{4} \mathrm{NO}_{3}$ Ringer solutions resulted in an increased rate of sperm swelling (Text-fig. 3). This result contradicts the theoretical possibility, suggested by the relatively great $\mathrm{pK}_{\mathrm{a}}$ values of HSCN and $\mathrm{HNO}_{3}$ (see above), that the rapid swelling of the spermatozoa in the $\mathrm{NH}_{4} \mathrm{SCN}$ and $\mathrm{NH}_{4} \mathrm{NO}_{3}$ Ringer solutions may reflect a potentiation brought about by a certain 'molecular-molecular' penetration (cf. Subsection B). It may be assumed, therefore, that the swelling of the spermatozoa in the ammonium salt solutions of the strong acids is caused by a 'molecular-ionic' penetration of the ammonium-salts, i.e. that the order of the penetration of the anions follows the series $\mathrm{SCN}^{-}>\mathrm{NO}_{3}{ }^{-}>\mathrm{I}^{-}>\mathrm{Br}^{-}, \mathrm{Cl}^{-}$, which is close to Hofmeister's (lyotropic) anion series, and that the rate-limiting step of the anion exchange is presumably that of $\mathrm{A}^{-}$(cf. Subsection A).

Spermatozoa did not swell in isosmotic Ringer solutions containing $\mathrm{NaCl}$, $\mathrm{NaBr}, \mathrm{NaI}, \mathrm{NaNO}_{3}$ or NaF. The ability of mammalian spermatozoa to maintain a constant volume in isosmotic $\mathrm{Na}^{+}$salt solutions (which, therefore, are strictly isotonic, in contrast to the actual ammonium salt solutions which are isosmotic but hypotonic) is apparently due to an inherent low permeability to cations, in combination with the operation of the $\mathrm{Na}^{+}-\mathrm{K}^{+}$pump (Uesugi \& Yamazoe, 1966; Quinn \& White, 1967, 1968a, b; O'Donnell \& Ellory, 1969, 1970). The slight swelling of the spermatozoa observed in the NaSCN Ringer solution (p. 45) implies a gain of osmotic material, i.e. $\mathrm{Na}^{+}$plus $\mathrm{SGN}^{-}$. A 
similar gain occurs when human erythrocytes are suspended in NaSCN Ringer solution (Funder \& Wieth, 1967).

\section{$V$. Influence on the kinetic activity of spermatozoa and sperm models of different anions and caffeine}

Mann \& Lutwak-Mann (1948) showed that fluoride abolishes both motility and fructolysis in ram spermatozoa. They attributed its action to the inhibition of enolase. The results of the experiments with sperm models (p. 48) are in line with the assumption of Lindahl \& Wedin (1963) that another effect of fluoride is to block the ATP-splitting and/or contractile activities of the flagellar fibres (cf. Morton \& Lardy, 1967).

The mechanisms of action of $\mathrm{Br}^{-}$and $\mathrm{SCN}^{-}$upon sperm motility are not known. The effect of $\mathrm{SCN}^{-}$upon sperm models suggests that this ion may bind to positively charged groups in the fibres which are vital for kinetic activity.

The $\mathrm{Br}^{-}$anion may be assumed to penetrate the cell membrane of living, intact spermatozoa more slowly than $\mathrm{SCN}^{-}$and $\mathrm{NO}_{3}{ }^{-}$(Text-fig. 2, see discussion in Subsection IV C). Since it rapidly potentiated sperm motility (Table 2, Text-fig. 4), only a low intracellular concentration of $\mathrm{Br}^{-}$may be needed to enhance such activity.

The ATP-reactivated flagellation of sperm models in the presence of $\mathrm{Br}^{-}$was very intense and could occur with forward progression and rotation. This indicates that the mechanism or subcellular organization responsible for rotation in normally swimming spermatozoa, which was assumed to have been destroyed in the sperm models of Bishop \& Hoffman-Berling (1959), was less affected by the serum treatment than by the digitonin extraction used by these authors.

Caffeine greatly increased the motility of living spermatozoa (Text-fig. 4, Table 2) but did not seem to affect the motility of ATP-reactivated sperm models. It may therefore act upon systems other than the flagellar fibres. Caffeine is an inhibitor of acetylcholinesterase (Nachmansohn \& Schneemann, 1945) which has a high activity in mammalian (Sekine, 1951) and fish spermatozoa (Tibbs, 1962). According to Nelson $(1962,1964)$, it is involved in the control of coordination and propagation of the flagellar waves. Caffeine also inhibits the phosphodiesterase which converts cyclic AMP into 5-AMP (Berthet, Sutherland \& Rall, 1957; Sutherland \& Rall, 1958) which may possibly be beneficial for motility. Furthermore, caffeine may, as in muscle (Bianchi, 1963; Isaacson \& Sandow, 1967), release $\mathrm{Ca}^{++}$from bound sites in the spermatozoa and inactivate a sperm-relaxing factor (cf. Bishop, 1962) and/or activate the ATPases of the flagellar fibres which are $\mathrm{Ca}^{++}$dependent (cf. Gordon \& Barnett, 1967).

The positive effects on sperm motility of $\mathrm{Br}^{-}$and caffeine may possibly be of value for increasing the motility of stored or of previously deep-frozen spermatozoa used for inseminations.

\section{ACKNOWLEDGMENTS}

I am much indebted to Professor P. E. Lindahl for valuable discussions and criticism and to Miss G. Thelin for drawing the figures. This investigation was 
supported by grants from the Hierta-Retzius Foundation and from the Faculty of Mathematics and Science of the University of Uppsala.

\section{REFERENCES}

BARer, R. (1956) Phase contrast and interference microscopy in cytology. In: Physical Techniques in BiologicaI Research, Vol. III. Eds G. Oster and A. W. Pollister. Academic Press, New York.

BÄrlund, H. (1929) Permeabilitätsstudien an Epidermiszellen von Rhoeo discolor. Acta bot. fenn. $5,1$.

Berthet, J., Sutherland, E. W. \& Rall, T. W. (1957) The assay of glucagon and epinephrine with use of liver homogenates. 7. biol. Chem. 229, 351.

Bianchi, C. P. (1963) Action on calcium movements in frog sartorius muscles by drugs producing rigor. F. cell. comp. Physiol. 61, 255.

Bisнop, D. W. (1962) Reactivation of extracted sperm models in relation to the mechanism of motility. In: Spermatozoan Motility, Ed. D. W. Bishop. Publ. No. 72, Am. Ass. Adv. Sci., Washington D.C.

Bishop, D. W. \& HoffMAN-Berling, H. (1959) Extracted mammalian sperm models. I. Preparation and reactivation with adenosine triphosphate. J. cell. comp. Physiol. 53, 445.

Bredderman, P. J. \& Foote, R. H. (1969) Volume of stressed bull spermatozoa and protoplasmic droplets, and the relationship of cell size to motility and fertility. F. Anim. Sci. 28, 496.

Davson, H. (1960) A text-book of general physiology. Churchill, London.

Davson, H. \& Danielli, J. F. (1952) The permeability of natural membranes. Cambridge University Press, London.

Drevius, L. O. (1968) On the mechanism of sperm immobilization induced by normal sera and antisemen sera. Expl Cell Res. 51, 362.

Drevius, L.-O. (1971a) The 'sperm-rise' test. F. Reprod. Fert. 24, 427.

Drevius, L.-O. (1971b) Permeability coefficients of bull spermatozoa for water and polyhydric alcohols. Expl Cell Res. (in press).

Drevius, L.-O. (1972a) Water content, specific gravity and concentrations of electrolytes in bull spermatozoa. 7. Reprod. Fert. 28, 15.

Drevius, L.-O. (1972b) Bull spermatozoa as osmometers. F. Reprod. Fert. 28, 29.

Drevius, L.-O. \& ERIKsson, H. (1966) Osmotic swelling of mammalian spermatozoa. Expl Cell Res. 42, 136.

Foote, R. H. \& Bredderman, P. J. (1969) Sizing of aging bull spermatozoa with an electronic counter. 7. Dairy Sci. 52, 117.

Funder, J. \& Wieth, J. O. (1967) Effects of some monovalent anions on fluxes of $\mathrm{Na}$ and $\mathrm{K}$, and on glucose metabolism of ouabain treated human red cells, Acta physiol. scand. 71, 168.

Gellhorn, E. (1922) Beiträge zur vergleichenden Physiologie der Spermatozoen. II. Mitteilung. Weiter Studien über Salzwirkungen. Pflügers Arch. ges. Physiol. 193, 555.

Gordon, M. \& BARRnetT, R. J. (1967) Fine structural cytochemical localizations of phosphatase activities of rat and guinea pig. Expl Cell Res. 48, 395.

HäGG, G. (1964) Allmän och oorganisk kemi. Almqvist \& Wiksell, Uppsala.

IsAACSON, A. \& SANDOW, A. (1967) Quinine and caffeine effects on ${ }^{45} \mathrm{Ca}$ movements in frog sartorius muscle. J. gen. Physiol. 50, 2109.

Jacons, M. H. (1940) Some aspects of cell permeability to weak electrolytes. Cold Spring Harb. Symp. quant. Biol. 8, 30.

Jacobs, M. H., Glassman, H. N. \& Parpart, A. K. (1938) Osmotic properties of the erythrocyte. XI. Differences in the permeability of the erythrocytes of two closely related species. $\mathcal{F}$. cell. comp. Physiol. 11, 479.

Jacobs, M. H. \& Parpart, A. K. (1938) Osmotic properties of the erythrocyte. X. On the permeability of the erythrocyte to ammonia and the ammonium ion. F. cell. comp. Physiol. 11, 175.

KING, T. E. \& MaNN, T. (1958) Sorbitol dehydrogenase in spermatozoa. Nature, Lond. $182,868$.

KING, T. E. \& ManN, T. (1959) Sorbitol metabolism in spermatozoa. Proc. R. Soc. B, $151,226$.

Kölliker, A. (1856) Physiologische Studien über die Samenflüssigkeit. Z. wiss. Zool. 7, 201.

Lardy, H. A. \& Phillips, P. H. (1941) The interrelations of oxidative and glycolytic processes as sources of energy of bull spermatozoa. Am. F. Physiol. 133, 602.

Lndahl, P. E. \& Wedin, K. (1963) Spermicidal effects studied with a photographic method. I. The effect of sodium fluoride. Expl Cell Res. 29, 242.

Mann, T. (1964) The biochemistry of semen and of the male reproductive tract. Methuen, London.

ManN, T. \& Lutwak-ManN, C. (1948) Studies on the metabolism of semen. 4. Aerobic and anaerobic utilization of fructose by spermatozoa and seminal vesicles. Biochem. 7. 43, 266.

Mann, T. \& White, I. G. (1956) Metabolism of glycerol, sorbitol and related compounds by spermatozoa. Nature, Lond. 178, 142. 
Merck Index of chemicals and drugs (1960) 7th edn, Merck \& Co. Inc., Rahway, N.Y.

Morton, B. E. \& LARDY, H. A. (1967) Cellular oxidative phosphorylation. I. Measurement in intact spermatozoa and other cells. Biochemistry, N.Y. 6, 43.

Nachmansohn, D. \& Schneeman, K. (1945) On the effects of drugs on cholinesterase. F. biol. Chem. 159, 239.

NELSON, L. (1962) Cytochemical aspects of spermatozoan motility. In: Spermatozoan Motility, Ed. D. W. Bishop. Publ. No. 72, Am. Ass. Adv. Sci., Washington D.C.

Nelson, L. (1964) Acetylcholinesterase in bull spermatozoa. 7. Reprod. Fert. 7, 65.

Odeblad, E. (1957) Proton magnetic resonance spectra of some types of cells. Ark. Zool. 11, No. 9, 123.

O'Donneli, J. M. \& Ellory, J. C. (1969) Cardiac glycoside binding and alkali cation transport in mature and epididymal bull spermatozoa. 7. Reprod. Fert. 20, 359.

O'Donnell, J. M. \& Ellory, J. G. (1970) The binding of cardiac glycosides to bull spermatozoa. Experientia, 26, 20.

O'Shea, T. \& Wales, R. G. (1965) Metabolism of sorbitol and fructose by ram spermatozoa. J. Reprod. Fert. 10, 353.

Ponder, E. (1940) The red cell as an osmometer. Cold Spring Harb. Symp. quant. Biol. 8, 133.

Pursley, G. R. \& Herman, H. A. (1950) Some effects of hypertonic and hypotonic solutions on the livability and morphology of bovine spermatozoa. F. Dairy Sci. 33, 220.

Qurns, P. J. \& Whrte, I. G. (1967) Active transport in dog spermatozoa. Biochem. F. 104, 328.

Quinn, P. J. \& White, I. G. (1968a) The transport of cations by ram and bull spermatozoa. Aust. $\mathcal{F}$. biol. Sci. 21, 781.

Quinn, P. J. \& WhITE, I. G. (1968b) Distribution of adenosinetriphosphatase activity in ram and bull spermatozoa. 7. Reprod. Fert. 15, 449.

Quins, P. J. \& WhITE, I. G. (1969) Osmotic shock of ram spermatozoa. F. Reprod. Fert. 18, 375.

ROThsChILD, LORD (1959) Anaerobic heat production of bull spermatozoa. II. The effects of changes in the colligative and other properties of the suspending medium. Proc. R. Soc. B, 151, 1.

Rothschild, LORD (1962) Sperm movement. Problems and observations. In: Spermatozoan Motility. Ed. D. W. Bishop. Publ. No. 72, Am. Ass. Adv. Sci., Washington D.C.

Sekine, T. (1951) Cholinesterase in pig spermatozoa. F. Biochem., Tokyo, 38, 171.

Sillé́, L. G. \& Martell, A. E. (Eds) (1964) Stability constants of metal-ion complexes. Special Publ. No. 17, p. 116. The Chemical Society, Burlington House, London.

Sutherland, E. W. \& Rali, T. W. (1958) Fractionation and characterization of a cyclic adenineribonucleotide formed by tissue particles. F. biol. Chem. 232, 1077.

TIBBS, J. (1962) Adenosine triphosphatase and acetylcholinesterase in relation to sperm motility. In: Spermatozoan Motility. Ed. D. W. Bishop. Publ. No. 72, Am. Ass. Adv. Sci., Washington D.C.

Uesugi, S. \& Yamazoe, S. (1966) Presence of sodium-potassium stimulated ATPase in boar epididymal spermatozoa. Nature, Lond. 209, 403.

UlRICH, H. (1934) Untersuchungen über die Permeation lipoidunlöslicher Nichtleiter von relativ grossem Molekularvolumen in die Erythrocyten von Saugetieren. Pfiügers Arch. ges. Physiol. 234, 42.

Weast, R. C. \& Selby, S. M. (Eds) (1966) Handbook of chemistry and physics, 47th edn. The Chemical Rubber Co., New York.

Whrte, I. G. (1957) Metabolism of glycerol and similar compounds by bull spermatozoa. Am. $\mathcal{F}$. Physiol. 189, 307. 